\title{
Mechanisms of oxysterol-induced carcinogenesis
}

\author{
Apinya Jusakul ${ }^{1,2}$, Puangrat Yongvanit ${ }^{1,2}$, Watcharin Loilome ${ }^{1,2}$, Nisana Namwat ${ }^{1,2}$, Rahul Kuver ${ }^{3^{*}}$
}

\begin{abstract}
Oxysterols are oxidation products of cholesterol that are generated by enzymatic reactions mediated by cytochrome P450 family enzymes or by non-enzymatic reactions involving reactive oxygen and nitrogen species. Oxysterols play various regulatory roles in normal cellular processes such as cholesterol homeostasis by acting as intermediates in cholesterol catabolism. Pathological effects of oxysterols have also been described, and various reports have implicated oxysterols in several disease states, including atherosclerosis, neurological disease, and cancer. Numerous studies show that oxysterols are associated with various types of cancer, including cancers of the colon, lung, skin, breast and bile ducts. The molecular mechanisms whereby oxysterols contribute to the initiation and progression of cancer are an area of active investigation. This review focuses on the current state of knowledge regarding the role of oxysterols in carcinogenesis. Mutagenicity of oxysterols has been described in both nuclear and mitochondrial DNA. Certain oxysterols such as cholesterol-epoxide and cholestanetriol have been shown to be mutagenic and genotoxic. Oxysterols possess pro-oxidative and pro-inflammatory properties that can contribute to carcinogenesis. Oxysterols can induce the production of inflammatory cytokines such as interleukin-8 and interleukin-1 $\beta$. Certain oxysterols are also involved in the induction of cyclo-oxygenase-2 expression. Inflammatory effects can also be mediated through the activation of liver-X-receptor, a nuclear receptor for oxysterols. Thus, several distinct molecular mechanisms have been described showing that oxysterols contribute to the initiation and progression of cancers arising in various organ systems.
\end{abstract}

\section{Introduction}

Oxysterols are derived from either enzymatic or non-enzymatic oxidation of cholesterol [1,2]. The chemical structures of oxysterols vary depending upon the number and position of oxygenated functional groups, and include keto-, hydroxyperoxy-, and epoxy forms (Figure 1). Enzymatic pathways of oxysterol production mainly involve cytochrome P450 family enzymes. Examples include 27hydroxylase (CYP27A1), the key enzyme in the alternative bile acid synthesis pathway which leads to the production of 27-hydroxycholesterol [3,4]; and $7 \alpha$-hydroxylase (CYP7A), the rate limiting enzyme in the classical bile acid synthesis pathway that leads to the production of $7 \alpha-$ hydroxycholesterol $[3,5]$. Certain oxysterols are produced by non-enzymatic oxidation (or auto-oxidation), a process that involves reactive oxygen and nitrogen species (ROS, RNS). Examples of ROS that participate in non-enzymatic oxidation of cholesterol include hydroxyl radical $(\cdot \mathrm{OH})$,

\footnotetext{
* Correspondence: kuver@u.washington.edu

${ }^{3}$ Department of Medicine, Division of Gastroenterology, University of Washington School of Medicine and the Puget Sound Veterans Affairs Health Care System, Seattle, WA, USA Full list of author information is available at the end of the article
}

hydrogen peroxide $\left(\mathrm{H}_{2} \mathrm{O}_{2}\right)$, singlet oxygen $\left({ }^{1} \mathrm{O}_{2}\right)$ and ozone $\left(\mathrm{O}_{3}\right)$ [6,7]. 7 $\alpha$-hydroperoxycholesterol is an example of a product of non-enzymatic oxidation of cholesterol which can be further oxidized by non-enzymatic and enzymatic means. Examples of oxysterols generated by this mechanism are 7-ketocholesterol and $7 \alpha / \beta$-hydroxycholesterol.

Numerous in vivo and in vitro studies have described biological effects of oxysterols [5]. Oxysterols can act as intermediates in cholesterol catabolism, especially in bile acid synthesis and are therefore involved in the elimination of excess cholesterol from the body. As oxysterols possess more hydrophilic moieties compared to the parent cholesterol molecule, they can pass more easily through cell membranes. This can occur because polar moieties inserting into hydrophobic regions of cell membranes result in redistribution of the sterol in conjunction with local re-ordering of the acyl chains $[3,8,9]$. Oxysterols are also able to regulate key enzymes in cholesterol turnover such as 3-hydroxy-3-methylglutaryl (HMG)-coenzyme A $(\mathrm{CoA})$ reductase [10], the rate-limiting enzyme in cholesterol synthesis.

Pathogenic effects of oxysterols has been described predominantly in cardiovascular diseases $[6,11,12]$ and
C Biomed Central 


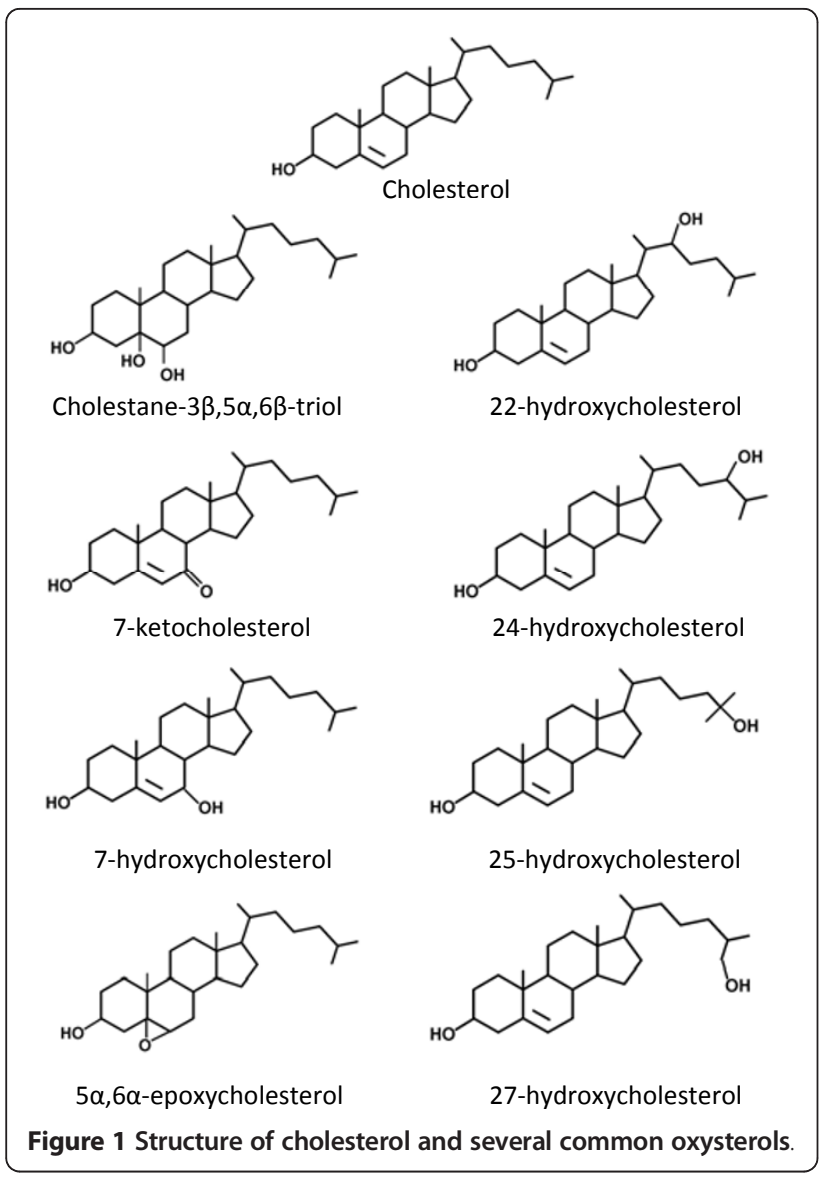

degenerative diseases such as age-related macular degeneration [13], Alzheimer's disease [14,15] and osteoporosis [16]. Several reports report a role for oxysterols in neurological disease (summarized in Table 1) [17-20].

The effects of cholesterol oxidation products on carcinogenesis was first reported by Bischoff and Rupp in 1946 [21]. Ovariectomized mice that received $10 \mathrm{mg}$ of crude progesterone in sesame oil showed a higher incidence of cancer than mice that received purified progesterone. Cholesterol oxidation products were found in mice that received the crude progesterone extract. This study provided circumstantial evidence that carcinogens may be produced endogenously from cholesterol. Subsequent studies have demonstrated the carcinogenic potential of specific oxysterols. For example, $6 \beta$-hydroperoxy-4-cholestane-3-one injected subcutaneously led to the development of local sarcomas in mice [22]. Cholesterol-5 $\alpha, 6 \alpha-$ epoxide also induced local sarcomas [23].

\section{Role of oxysterols in tissue-specific carcinogenesis Oxysterols and lung cancer}

An epidemiological study described the relationship between lung cancer risk and oxysterols. Using a nested case-control study design, smoking-independent associations between cholesterol oxidation and lung cancer risk were investigated. Six oxysterols ( $7 \alpha$-hydroxycholesterol, $7 \beta$-hydroxycholesterol, cholesterol- $\alpha$-epoxide, cholesterol- $\beta$-epoxide, cholestanetriol, 7-ketocholesterol and 7keto-pregnenolone), were measured in plasma of 20 lung cancer patients. The results showed slightly increased levels of all oxysterols compared with control with the exception of $7 \alpha$-hydroxycholesterol and cholesterol- $\alpha$-epoxide. Additionally, a risk analysis showed no statistical significant link between oxysterol concentrations and lung cancer development. When adjusted for participation in sports, however, the association between $7 \beta$-hydroxycholesterol levels and lung cancer was statistically significant. The data suggest that plasma levels of $7 \beta$-hydroxycholesterol are a smoking-independent predictor and biomarker for lung cancer risk [24]. Increased levels of $7 \beta$-hydroxycholesterol may be caused by lipid peroxidation, oxysterol dietary intake and individual differences in the metabolism of oxysterols.

Several reports describe the anti-cancer effects of $7 \beta$ hydroxycholesterol in lung cancer and various other types of cancer [25-28]. 7 $\beta$-hydroxycholesterol mediated a cytotoxic effect on human NCI-H460 lung cancer cells through the induction of apoptosis via caspase activation [29].

\section{Role of oxysterols in colon carcinogenesis}

Several reports have provided evidence that oxysterols contribute to gastrointestinal cancer development. Animal fat oxidation products, including oxysterols, have been linked to colon carcinogenesis. One possible mechanism for this effect is via upregulation of expression of transforming growth factor $-\beta 1$ (TGF- $\beta 1$ ) in macrophages and fibroblasts, cells which are present in

Table 1 Oxysterol disease associations

\begin{tabular}{|c|c|c|c|c|}
\hline Oxysterols & Cancer & Atherosclerosis & Neurological diseases & References \\
\hline 5,6-cholesterolepoxide & $\sqrt{ }$ & $\sqrt{ }$ & & {$[84,85]$} \\
\hline Cholestane- $3 \beta, 5 \alpha, 6 \beta$-triol & $\sqrt{ }$ & $\sqrt{ }$ & & {$[17,86,87]$} \\
\hline 25-hydroxycholesterol & & & $\sqrt{ }$ & {$[88]$} \\
\hline 24-hydroxycholesterol & & & $\sqrt{ }$ & [89-91] \\
\hline $\begin{array}{l}\text { 7-Hydroperoxy- } \\
\text { cholesterols }\end{array}$ & & $\sqrt{ }$ & & [92] \\
\hline 7-hydroxycholesterol & & $\sqrt{ }$ & & [93] \\
\hline
\end{tabular}


the tumor microenvironment [30]. TGF- $\beta 1$ is normally involved in promoting differentiation and apoptosis in intestinal epithelial cells. Colon cancer cells demonstrate decreased expression of TGF- $\beta 1$ type I and/or type II receptors [31]. Thus, colon cancer cells are less susceptible to the growth regulatory effects of TGF- $\beta 1$. An increased concentration of TGF- $\beta 1$ is thought to be involved in a selective elimination of neoplastic cells susceptible to the pro-apoptotic effects of this cytokine, thereby indirectly allowing the clonal expansion of TGF$\beta 1$-insensitive neoplastic cells $[32,33]$. Consequently, disruption of TGF- $\beta 1$ growth inhibition would support uncontrolled cell proliferation and transformation. Such alterations in TGF- $\beta 1$ receptor expression have been described in cancers of the colon [34], prostate [35], breast [36] and lung [37]. An oxysterol mixture composed of $7 \alpha$-hydroxycholesterol (43\%), $5 \alpha, 6 \alpha$-epoxycholesterol (32\%) and 5 $5,6 \beta$-epoxycholesterol (6\%) induced apoptosis in the human colon adenocarcinoma cell line $\mathrm{CaCo}-2$. The mitochondrial pathway of apoptosis was upregulated in these cells after stimulation by oxysterols as shown by a decrease in mitochondrial membrane potential, release of cytochrome c, and activation of caspase-3. The mechanism of oxysterol-induced upregulation of apoptosis in differentiated $\mathrm{CaCo}-2$ cells involved increased production of ROS by NADPH oxidase activation [38]. Excessive levels of ROS and pro-inflammatory cytokines likely contribute to impairment of enteric mucosal function [39].

Patients with ulcerative colitis are at risk for developing colon cancer. These patients excrete high levels of cholesterol, coprostanol and cholestane-3 $\beta-5 \alpha-6 \beta$ triol (cholestanetriol) in feces compared to patients with other digestive diseases and healthy controls [40]. However, the carcinogenic effect of oxysterols has not been demonstrated in rat colons. No colonic tumors were induced by sterols including cholesterol epoxide, cholestanetriol and cholesterol in standard and germ free female rats. Only lithocolic acid, a bile acid produced by bacterial oxidation of chenodeoxycholic acid in the colon, induced colon cancer in this model [41].

\section{Role of oxysterols in cholangiocarcinogenesis}

Oxysterols may also play a role in the development and progression of cholangiocarcinoma (CCA), a malignancy arising from intra- and extra-hepatic bile duct epithelial cells or cholangiocytes. A risk factor for the development of CCA in Thailand is chronic infection with the liver fluke, Opisthorchis viverrini $[42,43]$. Infection leads to accumulation of nitric oxide (NO) and oxygen radicals in inflamed tissue resulting in direct and indirect DNA damage both in animal and human studies [44-47]. We found significantly increased levels of 4cholesten-3-one and cholestanetriol in a hamster model of CCA induced by liver fluke infection combined with
$N$-nitrosodimethylamine treatment (unpublished data). Interleukin 6 (IL-6) is a potent mitogen for cholangiocytes and cholangiocarcinoma cells [48-50]. The role of oxysterols in mediating tumor formation in cholangiocytes was reported by Yoon et. al.[51]. These investigators examined the effect of 22(R)-hydroxycholesterol (22-HC) on cyclooxygenase-2 (COX-2) expression and found that this oxysterol stabilized the level of COX-2 mRNA via a p38-mitogen activated protein kinase (MAPK)-dependent mechanism leading to COX-2 protein accumulation in a CCA cell line. This induction of COX-2 could promote cellular replication and inhibit apoptosis [52] and thus contribute to the progression of CCA. In addition to induction of COX-2 expression, bile acids also enhance cellular levels of a potent antiapoptotic protein, myeloid cell leukemia protein 1 (Mcl1) [53]. Given the important role of apoptosis inhibition in carcinogenesis and the dominant anti-apoptotic effects of Mcl-1 in CCA cells, this observation may be important in understanding the tropism displayed by bile acid-induced CCA. Indeed, CCA appears to have co-opted the toxic bile milieu to promote growth and survival. Alteration of bile composition during chronic inflammation warrants further investigation as a mechanism of biliary tract carcinogenesis. This observation suggests that these tumors may not only have developed mechanisms to survive the toxic constituents in bile but may actually use bile to promote growth and survival.

Oxysterols were found in infected human hepatic bile, with $7 \alpha$-hydroxycholesterol and $7 \beta$-hydroxycholesterol present at significantly higher concentrations in infected than in uninfected bile. The levels of $7 \alpha$-hydroxycholesterol, 7 $\beta$-hydroxycholesterol, cholestanetriol, 7- $\alpha$ hydroxy-4-cholestane-3-one and 7-ketocholesterol were also positively correlated with $\mathrm{C}$-reactive protein (CRP) levels. These findings suggest that infection of biliary cells may be linked to the synthesis of oxysterols and consequently participate in the development of biliary diseases $[54,55]$.

\section{Mechanisms of oxysterols in carcinogenesis Mutagenicity of oxysterols}

The mutagenic effects of oxysterols were first described in1979. Smith et al. [56] reported this effect in air-aged samples of cholesterol on five strains of Salmonella typhimurium using the Ames method. Exposure of pure cholesterol to heating in air at $70^{\circ} \mathrm{C}$ or to $60^{\circ} \mathrm{C}$ or $\gamma$-radiation resulted in the genesis of mutagenic compounds. No mutagenic effect of cholesterol- $\alpha$-epoxide and cholesterol- $\beta$-epoxide was shown, similar to cholesterol. In a hamster model, cholesterol- $\alpha$-epoxide showed a weak mutagenic effect. V79 Chinese hamster lung fibroblasts treated with cholesterol- $\alpha$-epoxide induced 
8 -azaguanine-resistant mutants at frequencies that were 4.6 to 11.8 -fold higher than the spontaneous mutation rate in rats. Cholesterol- $\alpha$-epoxide accumulates in cells and can transform into cholestanetriol which possesses greater cytotoxicity and acts as a potent inhibitor of DNA synthesis. This modification causes a decrease in the mutagenic effects of cholesterol- $\alpha$-epoxide. Thus the mutagenicity of cholesterol- $\alpha$-epoxide in V79 Chinese hamster lung fibroblast cells may depend on the ability of cell to metabolize cholesterol-epoxide to cholestanetriol via epoxide hydrolase activity.

The genotoxicity of cholestanetriol using the Ames method and the generation of chromosomal aberrations has been demonstrated. Cholestanetriol, but not 7-ketocholesterol and cholesterol- $5 \alpha-6 \alpha$-epoxide, exhibited genotoxicity as determined by the rate of bacterial revertants in the absence of the metabolic activating enzyme (S9). In addition, cholestanetriol induced chromosomal aberrations in Chinese hamster ovary cells (CHO-K1) in the presence and absence of the S9 fraction. However, the degree of abnormalities in chromosomal structure was reduced with $S 9$ treatment when compared to no treatment. Anti-oxidant enzymes including catalase and superoxide dismutase can inhibit cholestanetriol-induced increases in bacterial revertant rates and chromosome aberration in $\mathrm{CHO}-\mathrm{K} 1$ cells. ROS production also increased in cholestanetriol-treated cells. These results suggest that genotoxicity of cholestanetriol may involve ROS generation [57]. Moreover, the effect of oxysterols on DNA mutation was reported by Gramajo et al.[58]. 7-ketocholesterol-treated culture significantly increased the degree of mitochondrial DNA (mtDNA) damage in the human RPE cell line (ARPE-19). Various studies also provide evidence that oxysterols enhance the production of ROS/RNS [57-62]. Oxysterols might enhance the production of ROS/RNS through alterations in the mitochondrial electron transport chain [59].

\section{Role of oxysterols in oxidative stress and inflammation}

Numerous studies have found a role for oxysterols in mediating pro-oxidative and pro-inflammatory processes in age-related degenerative diseases such as Alzheimer's disease and atherosclerosis $[6,13,63,64]$. The pro-oxidative and pro-inflammatory effect of $7 \alpha-, 7 \beta$-hydroxycholesterol, 7-ketocholesterol, cholesterol- $5 \alpha-6 \alpha$-epoxide, cholesterol- $\beta$-epoxide, 22R-, 22S-, 25- and 27-hydroxycholesterol were studied in U937 human promonocytic leukemia cells. $7 \beta$-hydroxycholesterol, 7-ketocholesterol and cholesterol- $\beta$-epoxide increased the production of singlet oxygen. The highest capacity to stimulate IL-8 secretion and enhance IL- 8 mRNA levels was observed in cells treated with $7 \beta$-hydroxycholesterol and 25-hydroxycholesterol [18]. Oxysterols that were oxidized at C7 enhanced the production of free radicals $[62,65,66]$. 7 ketocholesterol caused a decrease in cellular glutathione content, oxidation of polyunsaturated fatty acids and enhanced the production of ROS [62]. Moreover, 7-ketocholesterol enhanced IL-1 $\beta$ secretion in endothelial cells and participated in the recruitment of monocytes and $\mathrm{T}$ lymphocytes.

The cytotoxicity of 7-ketocholesterol and $7 \beta$-hydroxycholesterol involves induction of oxidative stress and down-regulation of anti-oxidative mechanisms [62]. These effects can be inhibited by anti-oxidant compounds such as lycopene, carotene, folate, glutathione, $\mathrm{N}$-acetylcysteine and resveratrol [64,65,67-70]. Notably, the pro-oxidative and cytotoxic effects may occur in the absence of activation of NADPH oxidase, as shown in J774A.1 macrophage cells [60,71]. NADPH oxidase plays a key role in oxysterol-induced ROS production in a human colon adenocarcinoma cell line [38].

Pro-inflammatory effects of oxysterols have also been described. 7-ketocholesterol, 7 $\beta$-hydroxycholesterol, 24hydroxycholesterol, 25-hydroxycholesterol and cholestanetriol have the capability to induce IL- 8 production. The pro-inflammatory effects of 25-hydroxycholesterol was increased in hypoxic culture conditions and potentiated lipopolysaccharide (LPS)-induced IL-1 $\beta$ secretion [72]. In U937 and THP-1 cells, 7 $\beta$-hydroxycholesterol and 25-hydroxycholesterol were involved in the recruitment of immunocompetent cells via MCP-1, MIP- $1 \beta$, TNF- $\alpha$, IL-1 $\beta$ and IL-8 [73]. In addition, certain oxysterols are involved in the induction of COX-2 expression which correlates with CRP levels $[51,55]$.

Pro-inflammatory effects of oxysterols also act at the transcriptional level. This can involve the activation of the liver-X-receptor (LXR) which is a nuclear receptor for certain oxysterols [74]. Pro-inflammatory oxysterols that exert their effect through LXR include 22R-hydroxycholesterol and 25-hydroxycholesterol but not 7 $\beta$-hydroxycholesterol [19]. 7 $\beta$-hydroxycholesterol appears to exert its pro-inflammatory effects at translational and post-translational levels. In $7 \beta$-hydroxycholesterol-treated U937 and THP-1 cells, increased IL- 8 secretion was found. This activation is associated with activation of the MEK/ERK1/2 signaling pathway [73]. The anti-inflammatory effects of oxysterols were also described in human macrophages incubated with 7-ketocholesterol, $7 \beta$ hydroxycholesterol, 25-hydroxycholesterol and 27-hydroxycholesterol before exposure to LPS-induced TNF- $\alpha$ secretion [75]. The 25-hydroxycholesterol which was produced from the stimulation of macrophage toll-like receptors (TLRs) can suppress IL-2-mediated stimulation of B cell proliferation and block IgA class switch recombination, resulting in decreased IgA production [76].

\section{Oxysterol signaling pathways}

Oxysterols may exert their cellular effects by binding to specific proteins and activating signaling cascades. In human breast cancer (MCF-7) cells, Silva et al. [77] 
found that oxysterols in the lipid fraction isolated from human osteoblast-like MG63 cell-conditioned medium (MG63CM) induced MCF-7 cell migration to bone tissue. Interestingly, insulin-like growth factor 1 increased the expression of oxysterol binding protein-related protein 7 (ORP7) in MCF-7 cells. Binding between these ligands and receptors altered the organization of lipid microdomains in cell membranes. Several oxysterolbinding proteins such as ORP7 and ORP 3 were recently reported to play a role in cell adhesion and migration through R-Ras, a small GTPase [78]. ORP3 is abundantly expressed in leukocytes and epithelial cells, and abnormally high expression levels are found in leukemias and solid tumors [79]. Oxysterol-binding proteinlike- 8 is overexpressed in hamster induced cholangiocarcinoma [80].

Oxysterols may act as secondary messengers in signaling transduction pathways. 22R-hydroxycholesterol stabilizes COX-2 mRNA via the 38-MAPK pathway in human cholangiocytes [51]. Hepatocellular carcinoma cells HepG2 and Huh7 senesce via alteration of p38 MAPK when treated with 5,6 secosterol [81]. Moreover, bile acids, which can be considered a type of oxysterol in bile, are known to activate various signaling cascades. Bile acids can stimulate cell proliferation by activation of the phosphatidylinositol3-kinase (PI3-K) pathway via a number of mitogen receptor tyrosine kinases such as epidermal growth factor receptor (EGFR) [82]. This activation is mediated by TGF$\alpha$, which is a ligand for EGFR. Bile acids that transactivate EGFR through a TGF- $\alpha$ dependent mechanism can be blocked by matrix metalloproteinase (MMP) inhibitors. This suggests that bile acids may activate the release of TGF- $\alpha$ through the induction of MMP. The simplest interpretation of this finding is that bile acids induce MMP activity by generating soluble TFG- $\alpha$ leading to activation of EGFR (Figure 2). Rats with obstructed bile ducts demonstrate increased cholangiocyte proliferation and secretion [83].

\section{Conclusions}

This review focuses on the mechanisms that may be operative in oxysterol-induced or associated carcinogenesis. In vitro and in vivo studies have demonstrated an association between different types of oxysterols and the development and progression of cancer of the colon, lung, breast and bile ducts. Oxysterols may play critical roles in multiple stages of carcinogenesis (Figure 3). First, they may be involved in tumor initiation by enhancing the production of ROS/RNS. Second, tumor promotion may be enhanced by oxysterols through upregulated expression of proteins such as COX-2 leading to the alteration of cellular phenotypes. In addition,

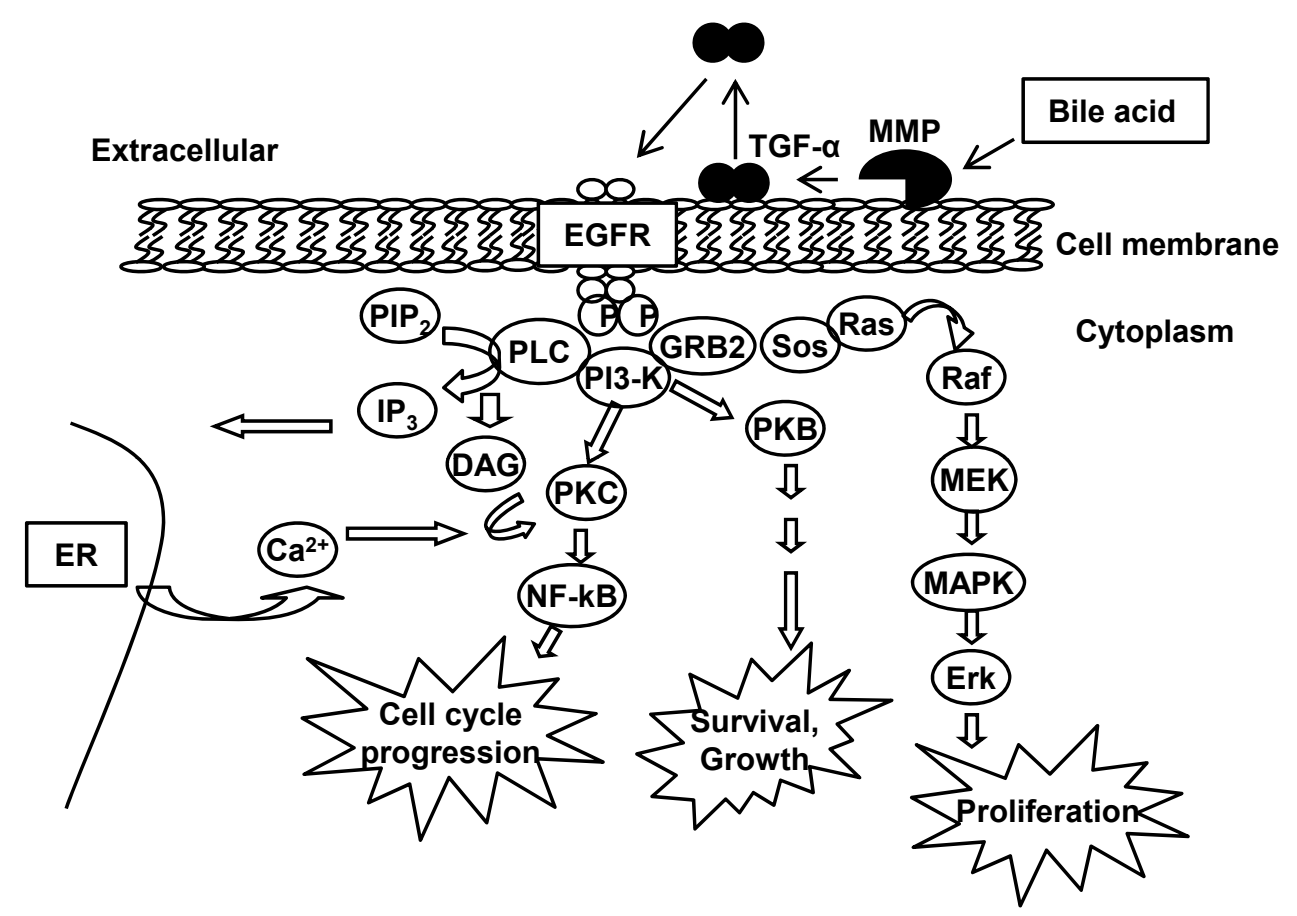

Figure 2 Bile acids transactivate EGFR in cholangiocytes. Bile acids induce a signaling transduction cascade through EGFR. Bile acids can stimulate Src kinase activity, enhance MMP activity and generate TGF- $\alpha$. Soluble TGF- $\alpha$ acts as the ligand for activation of EGFR. This activation induces signaling molecules such as protein kinase C (PKC), PI3-K and MAPK resulting in alterations in the cell cycle, cell growth, and cell survival (adapted from [53]. 


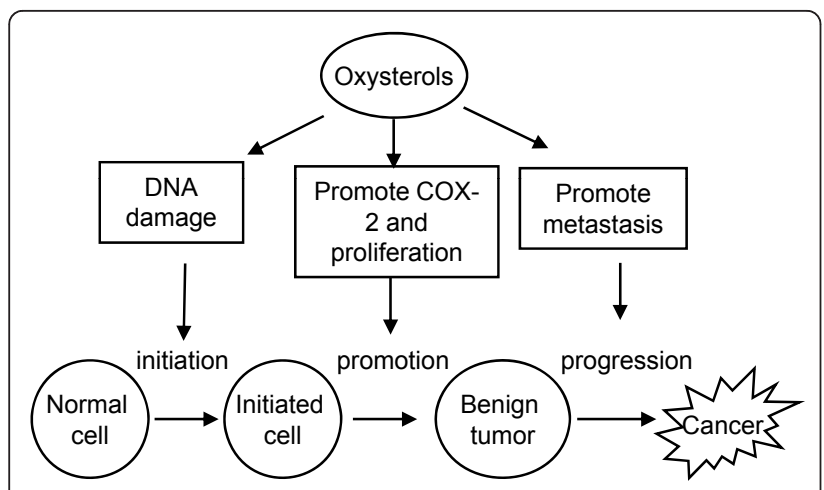

Figure 3 Effects of oxysterols on carcinogenesis. Oxysterols exert their effect on three stages of carcinogenesis by induction of DNA damage, enhancing production of COX-2 and stimulation of tumor cell migration $[51,57,77]$.

certain oxysterols can support cancer progression through the induction of migration. Oxysterols may exert their effect by binding to specific proteins and activating signaling cascades. Further investigations of oxysterols and their impact on carcinogenesis are required for developing improved strategies for the prevention and treatment of various types of cancer.

\section{Acknowledgements}

This work was supported by the Thailand Research Fund through Window II (BRG 5280020) and Royal Golden Jubilee Ph.D. Program (Grant No. PHD/ 0177/2549) to AJ and PY, and by NIH grant CA114403 to RK.

\section{Author details}

'Department of Biochemistry, Faculty of Medicine, Khon Kaen University, Khon Khaen 40002, Thailand. ' Liver Fluke and Cholangiocarcinoma Research Center, Faculty of Medicine, Khon Kaen University, Khon Kaen 40002,

Thailand. ${ }^{3}$ Department of Medicine, Division of Gastroenterology, University of Washington School of Medicine and the Puget Sound Veterans Affairs Health Care System, Seattle, WA, USA.

\section{Authors' contributions}

AJ wrote the manuscript. WL, PY, NN, and RK reviewed and revised the manuscript. All authors approved the final version of the manuscript.

\section{Competing interests}

The authors declare that they have no competing interests.

Received: 12 January 2011 Accepted: 9 March 2011

Published: 9 March 2011

\section{References}

1. Smith LL: Cholesterol autoxidation 1981-1986. Chem Phys Lipids 1987, 44:87-125.

2. Guardiola F, Codony R, Addis PB, Rafecas M, Boatella J: Biological effects of oxysterols: current status. Food Chem Toxicol 1996, 34:193-211.

3. Bjorkhem I: Do oxysterols control cholesterol homeostasis? I Clin Invest 2002, 110:725-730.

4. Russell DW: Oxysterol biosynthetic enzymes. Biochim Biophys Acta 2000, 1529:126-135.

5. Schroepfer GJ Jr: Oxysterols: modulators of cholesterol metabolism and other processes. Physiol Rev 2000, 80:361-554.

6. Brown AJ, Jessup W: Oxysterols and atherosclerosis. Atherosclerosis 1999, 142:1-28.
7. Brown AJ, Jessup W: Oxysterols: Sources, cellular storage and metabolism, and new insights into their roles in cholesterol homeostasis. Mol Aspects Med 2009, 30:111-122.

8. Diczfalusy U, Lund E, Lutjohann D, Bjorkhem I: Novel pathways for elimination of cholesterol by extrahepatic formation of side-chain oxidized oxysterols. Scand J Clin Lab Invest Suppl 1996, 226:9-17.

9. Meaney S, Bodin K, Diczfalusy U, Bjorkhem I: On the rate of translocation in vitro and kinetics in vivo of the major oxysterols in human circulation: critical importance of the position of the oxygen function. $J$ Lipid Res 2002, 43:2130-2135.

10. Bjorkhem I: Are side-chain oxidized oxysterols regulators also in vivo? J Lipid Res 2009, 50(Suppl):S213-218.

11. Alkazemi D, Egeland G, Vaya J, Meltzer S, Kubow S: Oxysterol as a marker of atherogenic dyslipidemia in adolescence. J Clin Endocrinol Metab 2008, 93:4282-4289.

12. van Reyk DM, Brown AJ, Hult'en LM, Dean RT, Jessup W: Oxysterols in biological systems: sources, metabolism and pathophysiological relevance. Redox Rep 2006, 11:255-262.

13. Malvitte L, Montange T, Joffre C, Vejux A, Maiza C, Bron A, Creuzot-Garcher C, Lizard G: Analogies between atherosclerosis and age-related maculopathy: expected roles of oxysterols. J Fr Ophthalmol 2006, 29:570-578.

14. Leoni V: Oxysterols as markers of neurological disease-a review. Scand J Clin Lab Invest 2009, 69:22-25.

15. Kolsch H, Lutjohann D, von Bergmann K, Heun R: The role of 24Shydroxycholesterol in Alzheimer's disease. J Nutr Health Aging 2003, 7:37-41.

16. Liu H, Yuan L, Xu S, Wang K, Zhang T: Cholestane-3beta,5alpha,6beta-triol inhibits osteoblastic differentiation and promotes apoptosis of rat bone marrow stromal cells. J Cell Biochem 2005, 96:198-208.

17. Sevanian A, Peterson AR: The cytotoxic and mutagenic properties of cholesterol oxidation products. Food Chem Toxicol 1986, 24:1103-1110.

18. Lemaire-Ewing S, Prunet C, Montange T, Vejux A, Berthier A, Bessede G, Corcos L, Gambert P, Neel D, Lizard G: Comparison of the cytotoxic, prooxidant and pro-inflammatory characteristics of different oxysterols. Cell Biol Toxicol 2005, 21:97-114

19. Vejux A, Malvitte L, Lizard G: Side effects of oxysterols: cytotoxicity, oxidation, inflammation, and phospholipidosis. Braz J Med Biol Res 2008, 41:545-556.

20. Vejux A, Lizard G: Cytotoxic effects of oxysterols associated with human diseases: Induction of cell death (apoptosis and/or oncosis), oxidative and inflammatory activities, and phospholipidosis. Mol Aspects Med 2009, 30:153-170.

21. Bischoff F, Rupp JJ: The production of a carcinogenic agent in the degration of cholesterol to progesterone. Cancer Res 1946, 6:403-409.

22. Bischoff F: Cocarcinogenic activity of cholesterol oxidation products and sesame oil. JNCl 1957, 19:977-987.

23. Bischoff F: Carcinogenic effects of steroids. Adv Lipid Res 1969, 7:165-244.

24. Linseisen J, Wolfram G, Miller AB: Plasma 7beta-hydroxycholesterol as a possible predictor of lung cancer risk. Cancer Epidemiol Biomarkers Prev 2002, 11:1630-1637.

25. Christ M, Ji YH, Moog C, Pannecoucke X, Schmitt G, Bischoff P, Luu B: Antitumor activity of oxysterols. Effect of two water-soluble monophosphoric acid diesters of 7 beta-hydroxycholesterol on mastocytoma P815 in vivo. Anticancer Res 1991, 11:359-364.

26. Christ M, Luu B, Mejia JE, Moosbrugger I, Bischoff P: Apoptosis induced by oxysterols in murine lymphoma cells and in normal thymocytes. Immunology 1993, 78:455-460.

27. Aupeix K, Weltin D, Mejia JE, Christ M, Marchal J, Freyssinet JM, Bischoff P. Oxysterol-induced apoptosis in human monocytic cell lines. Immunobiology 1995, 194:415-428.

28. Lizard G, Deckert V, Dubrez L, Moisant M, Gambert P, Lagrost L: Induction of apoptosis in endothelial cells treated with cholesterol oxides. Am J Pathol 1996, 148:1625-1638.

29. Kang KA, Chae S, Lee KH, Park MT, Lee SJ, Lee YS, Hyun JW: Cytotoxic effect of 7beta-hydroxycholesterol on human $\mathrm{NCl}-\mathrm{H} 460$ lung cancer cells. Biol Pharm Bull 2005, 28:1377-1380.

30. Leonarduzzi G, Scavazza A, Biasi F, Chiarpotto E, Camandola S, Vogel S, Dargel R, Poli G: The lipid peroxidation end product 4-hydroxy-2,3nonenal up-regulates transforming growth factor beta1 expression in the macrophage lineage: a link between oxidative injury and fibrosclerosis. Faseb J 1997, 11:851-857. 
31. Biasi F, Tessitore L, Zanetti D, Cutrin JC, Zingaro B, Chiarpotto E, Zarkovic N, Serviddio G, Poli G: Associated changes of lipid peroxidation and transforming growth factor beta1 levels in human colon cancer during tumour progression. Gut 2002, 50:361-367.

32. Biasi F, Mascia C, Poli G: The contribution of animal fat oxidation products to colon carcinogenesis through modulation of TGF-beta1 signaling. Carcinogenesis 2008, 29:890-894.

33. Biasi F, Mascia C, Poli G: TGFbeta1 expression in colonic mucosa: modulation by dietary lipids. Genes Nutr 2007, 2:233-243.

34. Winesett MP, Ramsey GW, Barnard JA: Type II TGF(beta) receptor expression in intestinal cell lines and in the intestinal tract. Carcinogenesis 1996, 17:989-995.

35. Landstrom M, Eklov S, Colosetti P, Nilsson S, Damber JE, Bergh A, Funa K: Estrogen induces apoptosis in a rat prostatic adenocarcinoma: association with an increased expression of TGF-beta 1 and its type-I and type-II receptors. Int J Cancer 1996, 67:573-579.

36. Sun L, Wu G, Willson JK, Zborowska E, Yang J, Rajkarunanayake I, Wang J, Gentry LE, Wang XF, Brattain MG: Expression of transforming growth factor beta type II receptor leads to reduced malignancy in human breast cancer MCF-7 cells. J Biol Chem 1994, 269:26449-26455.

37. Kim WS, Park C, Jung YS, Kim HS, Han J, Park CH, Kim K, Kim J, Shim YM, Park K: Reduced transforming growth factor-beta type II receptor (TGFbeta RII) expression in adenocarcinoma of the lung. Anticancer Res 1999, 19:301-306.

38. Biasi F, Mascia C, Astegiano M, Chiarpotto E, Nano M, Vizio B, Leonarduzzi G, Poli G: Pro-oxidant and proapoptotic effects of cholesterol oxidation products on human colonic epithelial cells: a potential mechanism of inflammatory bowel disease progression. Free Radic Biol Med 2009, 47:1731-1741.

39. Forsyth CB, Banan A, Farhadi A, Fields JZ, Tang Y, Shaikh M, Zhang $L$, Engen PA, Keshavarzian A: Regulation of oxidant-induced intestinal permeability by metalloprotease-dependent epidermal growth factor receptor signaling. J Pharmacol Exp Ther 2007, 321:84-97.

40. Reddy BS, Martin CW, Wynder EL: Fecal bile acids and cholesterol metabolites of patients with ulcerative colitis, a high-risk group for development of colon cancer. Cancer Res 1977, 37:1697-1701.

41. Reddy BS, Watanabe K: Effect of cholesterol metabolites and promoting effect of lithocholic acid in colon carcinogenesis in germ-free and conventional F344 rats. Cancer Res 1979, 39:1521-1524.

42. Haswell-Elkins MR, Sithithaworn P, Elkins D: Opisthorchis viverrini and cholangiocarcinoma in Northeast Thailand. Parasitol Today 1992, 8:86-89.

43. Elkins DB, Mairiang E, Sithithaworn P, Mairiang P, Chaiyakum J, Chamadol N, Loapaiboon V, Haswell-Elkins MR: Cross-sectional patterns of hepatobiliary abnormalities and possible precursor conditions of cholangiocarcinoma associated with Opisthorchis viverrini infection in humans. Am J Trop Med Hyg 1996, 55:295-301.

44. Pinlaor S, Yongvanit P, Hiraku Y, Ma N, Semba R, Oikawa S, Murata M, Sripa B, Sithithaworn P, Kawanishi S: 8-nitroguanine formation in the liver of hamsters infected with Opisthorchis viverrini. Biochem Biophys Res Commun 2003, 309:567-571.

45. Dechakhamphu S, Pinlaor S, Sitthithaworn P, Bartsch H, Yongvanit P: Accumulation of miscoding etheno-DNA adducts and highly expressed DNA repair during liver fluke-induced cholangiocarcinogenesis in hamsters. Mutat Res 2010, 691:9-16.

46. Thanan R, Murata M, Pinlaor S, Sithithaworn P, Khuntikeo N, Tangkanakul W, Hiraku Y, Oikawa S, Yongvanit P, Kawanishi S: Urinary 8-oxo-7,8-dihydro-2'deoxyguanosine in patients with parasite infection and effect of antiparasitic drug in relation to cholangiocarcinogenesis. Cancer Epidemiol Biomarkers Prev 2008, 17:518-524.

47. Dechakhamphu S, Pinlaor S, Sitthithaworn P, Nair J, Bartsch H, Yongvanit P: Lipid peroxidation and etheno DNA adducts in white blood cells of liver fluke-infected patients: protection by plasma alpha-tocopherol and praziquantel. Cancer Epidemiol Biomarkers Prev 2010, 19:310-318.

48. Park J, Tadlock L, Gores GJ, Patel T: Inhibition of interleukin 6-mediated mitogen-activated protein kinase activation attenuates growth of a cholangiocarcinoma cell line. Hepatology 1999, 30:1128-1133.

49. Goydos JS, Brumfield AM, Frezza E, Booth A, Lotze MT, Carty SE: Marked elevation of serum interleukin- 6 in patients with cholangiocarcinoma: validation of utility as a clinical marker. Ann Surg 1998, 227:398-404.

50. Sripa B, Mairiang E, Thinkhamrop B, Laha T, Kaewkes S, Sithithaworn P, Tessana S, Loukas A, Brindley PJ, Bethony JM: Advanced periductal fibrosis from infection with the carcinogenic human liver fluke Opisthorchis viverrini correlates with elevated levels of interleukin-6. Hepatology 2009, 50:1273-1281.

51. Yoon JH, Canbay AE, Werneburg NW, Lee SP, Gores GJ: Oxysterols induce cyclooxygenase-2 expression in cholangiocytes: implications for biliary tract carcinogenesis. Hepatology 2004, 39:732-738.

52. Cao Y, Prescott SM: Many actions of cyclooxygenase-2 in cellular dynamics and in cancer. J Cell Physiol 2002, 190:279-286.

53. Yoon JH, Werneburg NW, Hiquchi H, Canbay AE, Kaufmann SH, Akgul C, Edwards SW, Gores GJ: Bile acids inhibit Mcl-1 protein turnover via an epidermal growth factor receptor/Raf-1-dependent mechanism. Cancer Res 2002, 62:6500-6505.

54. Yoshida T, Matsuzaki Y, Haigh WG, Fukushima S, Ikezawa K, Tanaka N, Lee SP: Origin of oxysterols in hepatic bile of patients with biliary infection. Am J Gastroenterol 2003, 98:2275-2280.

55. Yoshida T, Klinkspoor JH, Kuver R, Poot M, Rabinovitch PS, Wrenn SP, Kaler EW, Lee SP: Effects of bile salts on cholestan-3beta, 5alpha, 6betatriol-induced apoptosis in dog gallbladder epithelial cells. Biochim Biophys Acta 2001, 1530:199-208.

56. Smith LL, Smart VB, Ansari GA: Mutagenic cholesterol preparations. Mutat Res 1979, 68:23-30

57. Cheng YW, Kang JJ, Shih YL, Lo YL, Wang CF: Cholesterol-3-beta, 5-alpha, 6-beta-triol induced genotoxicity through reactive oxygen species formation. Food Chem Toxicol 2005, 43:617-622.

58. Gramajo AL, Zacharias LC, Neekhra A, Luthra S, Atilano SR, Chwa M, Brown DJ, Kuppermann BD, Kenney MC: Mitochondrial DNA damage induced by 7-ketocholesterol in human retinal pigment epithelial cells in vitro. Invest Ophthalmol Vis Sci 2010, 51:1164-1170.

59. Liu H, Wang T, Huang K: Cholestane-3beta, 5alpha, 6beta-triol-induced reactive oxygen species production promotes mitochondrial dysfunction in isolated mice liver mitochondria. Chem Biol Interact 2009, 179:81-87.

60. Leonarduzzi G, Vizio B, Sottero B, Verde V, Gamba P, Mascia C, Chiarpotto E, Poli G, Biasi F: Early involvement of ROS overproduction in apoptosis induced by 7-ketocholesterol. Antioxid Redox Signal 2006, 8:375-380.

61. Panini SR, Sinensky MS: Mechanisms of oxysterol-induced apoptosis. Curr Opin Lipidol 2001, 12:529-533.

62. Lizard G, Gueldry S, Sordet O, Monier S, Athias A, Miguet C, Bessede G, Lemaire S, Solary E, Gambert P: Glutathione is implied in the control of 7ketocholesterol-induced apoptosis, which is associated with radical oxygen species production. Faseb J 1998, 12:1651-1663.

63. Rodriguez IR, Larrayoz IM: Cholesterol oxidation in the retina: implications of 7KCh formation in chronic inflammation and age-related macular degeneration. J Lipid Res 2010, 51:2847-2862.

64. Dugas B, Charbonnier S, Baarine M, Ragot K, Delmas D, Menetrier F, Lherminier J, Malvitte L, Khalfaoui T, Bron A, et al: Effects of oxysterols on cell viability, inflammatory cytokines, VEGF, and reactive oxygen species production on human retinal cells: cytoprotective effects and prevention of VEGF secretion by resveratrol. Eur J Nutr 2010, 49:435-446.

65. Miguet-Alfonsi C, Prunet C, Monier S, Bessede G, Lemaire-Ewing S, Berthier A, Menetrier F, Neel D, Gambert P, Lizard G: Analysis of oxidative processes and of myelin figures formation before and after the loss of mitochondrial transmembrane potential during 7 betahydroxycholesterol and 7-ketocholesterol-induced apoptosis: comparison with various pro-apoptotic chemicals. Biochem Pharmacol 2002, 64:527-541.

66. O'Callaghan YC, Woods JA, O'Brien NM: Comparative study of the cytotoxicity and apoptosis-inducing potential of commonly occurring oxysterols. Cell Biol Toxicol 2001, 17:127-137.

67. Palozza P, Simone R, Catalano A, Boninsegna A, Bohm V, Frohlich K, Mele MC, Monego G, Ranelletti FO: Lycopene prevents 7-ketocholesterolinduced oxidative stress, cell cycle arrest and apoptosis in human macrophages. J Nutr Biochem 2010, 21:34-46.

68. Palozza P, Simone R, Catalano A, Monego G, Barini A, Mele MC, Parrone N, Trombino S, Picci N, Ranelletti FO: Lycopene prevention of oxysterolinduced proinflammatory cytokine cascade in human macrophages: inhibition of NF-kappaB nuclear binding and increase in PPARgamma expression. J Nutr Biochem 2011, 22:259-68.

69. Han JH, Kim YJ, Han ES, Lee CS: Prevention of 7-ketocholesterol-induced mitochondrial damage and cell death by calmodulin inhibition. Brain Res 2007, 1137:11-19. 
70. Lizard G, Miguet C, Bessede G, Monier S, Gueldry S, Neel D, Gambert P: Impairment with various antioxidants of the loss of mitochondrial transmembrane potential and of the cytosolic release of cytochrome c occuring during 7-ketocholesterol-induced apoptosis. Free Radic Biol Med 2000, 28:743-753.

71. Biasi F, Leonarduzzi G, Vizio B, Zanetti D, Sevanian A, Sottero B, Verde V, Zingaro B, Chiarpotto E, Poli G: Oxysterol mixtures prevent proapoptotic effects of 7-ketocholesterol in macrophages: implications for proatherogenic gene modulation. Faseb J 2004, 18:693-695.

72. Rydberg EK, Salomonsson L, Hulten LM, Noren K, Bondjers G, Wiklund O, Bjornheden T, Ohlsson BG: Hypoxia increases 25-hydroxycholesterolinduced interleukin-8 protein secretion in human macrophages. Atherosclerosis 2003, 170:245-252.

73. Prunet $C$, Montange $T$, Vejux A, Laubriet A, Rohmer JF, Riedinger JM, Athias A, Lemaire-Ewing S, Neel D, Petit JM, et al: Multiplexed flow cytometric analyses of pro- and anti-inflammatory cytokines in the culture media of oxysterol-treated human monocytic cells and in the sera of atherosclerotic patients. Cytometry A 2006, 69:359-373.

74. Edwards PA, Kennedy MA, Mak PA: LXRs: Oxysterol-activated nuclear receptors that regulate genes controlling lipid homeostasis. Vascul Pharmacol 2002, 38:249-256.

75. Englund MC, Karlsson AL, Wiklund O, Bondjers G, Ohlsson BG: 25hydroxycholesterol induces lipopolysaccharide-tolerance and decreases a lipopolysaccharide-induced TNF-alpha secretion in macrophages. Atherosclerosis 2001, 158:61-71.

76. Bauman DR, Bitmansour AD, McDonald JG, Thompson BM, Liang G, Russell DW: 25-Hydroxycholesterol secreted by macrophages in response to Toll-like receptor activation suppresses immunoglobulin A production. Proc Natl Acad Sci USA 2009, 106:16764-16769.

77. Silva J, Beckedorf A, Bieberich E: Osteoblast-derived oxysterol is a migration-inducing factor for human breast cancer cells. J Biol Chem 2003, 278:25376-25385

78. Goldfinger LE, Ptak C, Jeffery ED, Shabanowitz J, Han J, Haling JR, Sherman NE, Fox JW, Hunt DF, Ginsberg MH: An experimentally derived database of candidate Ras-interacting proteins. J Proteome Res 2007, 6:1806-1811.

79. Lehto M, Mayranpaa MI, Pellinen T, Ihalmo P, Lehtonen S, Kovanen PT, Groop PH, Ivaska J, Olkkonen VM: The R-Ras interaction partner ORP3 regulates cell adhesion. J Cell Sci 2008, 121:695-705.

80. Loilome W, Yongvanit P, Wongkham C, Tepsiri N, Sripa B, Sithithaworn P, Hanai S, Miwa M: Altered gene expression in Opisthorchis viverriniassociated cholangiocarcinoma in hamster model. Mol Carcinog 2006, 45:279-287.

81. Anticoli S, Arciello M, Mancinetti A, De Martinis M, Ginaldi L, luliano L, Balsano C: 7-ketocholesterol and 5,6-secosterol modulate differently the stress-activated mitogen-activated protein kinases (MAPKs) in liver cells. J Cell Physiol 2010, 222:586-595.

82. Werneburg NW, Yoon JH, Higuchi H, Gores GJ: Bile acids activate EGF receptor via a TGF-alpha-dependent mechanism in human cholangiocyte cell lines. Am J Physiol Gastrointest Liver Physiol 2003, 285: G31-36.

83. Alpini G, Glaser S, Alvaro D, Ueno Y, Marzioni M, Francis H, Baiocchi L, Stati T, Barbaro B, Phinizy JL, et al: Bile acid depletion and repletion regulate cholangiocyte growth and secretion by a phosphatidylinositol 3-kinase-dependent pathway in rats. Gastroenterology 2002, 123:1226-1237.

84. Sevanian A, Peterson AR: Cholesterol epoxide is a direct-acting mutagen. Proc Natl Acad Sci USA 1984, 81:4198-4202.

85. Garcia-Cruset S, Carpenter KL, Guardiola F, Stein BK, Mitchinson MJ: Oxysterol profiles of normal human arteries, fatty streaks and advanced lesions. Free Radic Res 2001, 35:31-41.

86. Lo WB, Black HS: Formation of cholesterol-derived photoproducts in human skin. J Invest Dermatol 1972, 58:278-283.

87. Liao PL, Cheng YW, Li CH, Lo YL, Kang JJ: Cholesterol-3-beta, 5-alpha, 6beta-triol induced PI(3)K-Akt-eNOS-dependent cyclooxygenase-2 expression in endothelial cells. Toxicol Lett 2009, 190:172-178.

88. Gueguen Y, Bertrand P, Ferrari L, Batt AM, Siest G: Control of apolipoprotein E secretion by 25-hydroxycholesterol and proinflammatory cytokines in the human astrocytoma cell line CCFSTTG1. Cell Biol Toxicol 2001, 17:191-199.
89. Kolsch H, Lutjohann D, Tulke A, Bjorkhem I, Rao ML: The neurotoxic effect of 24-hydroxycholesterol on SH-SY5Y human neuroblastoma cells. Brain Res 1999, 818:171-175.

90. Lutjohann D, Papassotiropoulos A, Bjorkhem I, Locatelli S, Bagli M, Oehring RD, Schlegel U, Jessen F, Rao ML, von Bergmann K, Heun R: Plasma 24S-hydroxycholesterol (cerebrosterol) is increased in Alzheimer and vascular demented patients. J Lipid Res 2000, 41:195-198.

91. Bretillon L, Siden A, Wahlund LO, Lutjohann D, Minthon L, Crisby M, Hillert J, Groth CG, Diczfalusy U, Bjorkhem I: Plasma levels of 24Shydroxycholesterol in patients with neurological diseases. Neurosci Lett 2000, 293:87-90.

92. Brown AJ, Leong SL, Dean RT, Jessup W: 7-Hydroperoxycholesterol and its products in oxidized low density lipoprotein and human atherosclerotic plaque. J Lipid Res 1997, 38:1730-1745.

93. Liu Y, Hulten LM, Wiklund O: Macrophages isolated from human atherosclerotic plaques produce IL-8, and oxysterols may have a regulatory function for IL-8 production. Arterioscler Thromb Vasc Biol 1997, 17:317-323.

doi:10.1186/1476-511X-10-44

Cite this article as: Jusakul et al:: Mechanisms of oxysterol-induced carcinogenesis. Lipids in Health and Disease 2011 10:44.

\section{Submit your next manuscript to BioMed Central and take full advantage of:}

- Convenient online submission

- Thorough peer review

- No space constraints or color figure charges

- Immediate publication on acceptance

- Inclusion in PubMed, CAS, Scopus and Google Scholar

- Research which is freely available for redistribution

Submit your manuscript at www.biomedcentral.com/submit
C) Biomed Central 